\title{
The first possible remingtonocetid stem whale from North America
}

Mark D. Uhen and Carlos Mauricio Peredo

Acta Palaeontologica Polonica 66 (1), 2021: 77-83 doi:https://doi.org/10.4202/app.00799.2020

Remingtonocetid cetaceans are a group of stem whales known from the Indo-Pakistan and North African Tethys Ocean. An unusual tooth was discovered by Peter J. Harmatuk in 1973 in the middle Eocene Superior Stone Quarry (now the Martin Marietta Quarry) near Castle Hayne, North Carolina, USA. Here we identify this tooth as a premolar of a possible member of the Remingtonocetidae, which would extend the range of this family across the Atlantic to eastern North America. This partial tooth includes most of the crown (missing the mesial end) and the posterior root. The tooth bears a single central cusp and a worn accessory cusp on the posterior end. This tooth most closely resembles premolars of Remingtonocetus and is rather dissimilar to premolars of other archaeocetes known from the middle Eocene of North America, such as the families Protocetidae and Basilosauridae. This new record potentially expands the geographic distribution of the amphibious cetacean family Remingtonocetidae across the Atlantic.

Key words: Mammalia, Archaeocete, Remingtonocetidae, middle Eocene, Castle Hayne Formation, North Carolina, USA.

Mark D. Uhen [muhen@gmu.edu], George Mason University, Department of Atmospheric, Oceanic, and Earth Sciences, MSN 6E2, Fairfax, VA 22030, USA.

Carlos M. Peredo [cmperedo@umich.edu], Univeristiy of Michigan, Department of Earth and Environmental Science, Ann Arbor, MI 48109, USA; Texas A\&M University Galveston, Department of Marine Biology Galveston, TX 77553, USA.

This is an open-access article distributed under the terms of the Creative Commons Attribution License (for details please see creativecommons.org), which permits unrestricted use, distribution, and reproduction in any medium, provided the original author and source are credited. 
For Full text $(469.6 \mathrm{kB})$ ।

FoF 5 Supplementary file $(604.4 \mathrm{kB})$ 